\title{
Early Effects of Two Productive Systems about the Quality of a Hapludoll from Formosa
}

\author{
Baridón Juan E. \\ Rigonatto Gabriela M. \\ Laboratorio de Aguas, Suelos y Forrajes \\ Centro de Validación de Tecnologías Agropecuarias \\ Ibarreta, Formosa \\ Argentina \\ Novella Cristian \\ Departamento de Ambiente y Recursos Naturales \\ Facultad de Ciencias Agrarias y Forestales \\ Universidad Nacional de La Plata \\ La Plata, Buenos Aires \\ Argentina
}

\begin{abstract}
There have been many changes in the use of soil in the northeast of Argentina for years, with relevant progress in the annual crops in competence with the traditional uses of the ground, a process that some authors call agriculturization. The goal of this work was to quantify, after five years of clearing, the effects of handling two systems over the Hapludoll from the central region of Formosa, Argentina. Three uses of the soil were analyzed: native degraded forest (NF), considered as a witness situation; continual agriculture in direct sowing (CA), and cattle raising (CR)in implanted pasture. Six possible quality indicators were used: $\mathrm{pH}$, oxidizable organic carbon $(O O C)$, particulate organic carbon (POC), structural stability (SS), total nitrogen (TN) and bulk density (BD). The POC resulted the more affected indicator in $C A$ and $C R$. The variables $p H, O O C, P O C$, SS and BD resulted early indicators in the loss of soil quality. The continual agriculture in direct sowing produced the largest damage in the edaphic system. Five years of implanted pasture only mitigated the deterioration of the soil, without making improvements on the soil quality itself with respect to degraded native forest.
\end{abstract}

Keywords: indicators, particle carbon, agriculturization

\section{Introduction}

By the year 2050, it is estimated an increase of $38 \%$ in the world population. It will rise from 6.987 to 9.587 million people (Population Reference Bureau, 2013). With this demographic setting, accompanied by the increased demand for food, the required response consists in the production growth, particularly in countries such as Argentina, with propitious soil and climate conditions, and productive potentiality not used yet.

The advance of annual crops over different environments, in competence with the traditional uses of the ground, has been defined for some authors as "agriculturization" (Baridón and Casas, 2014). Nowadays, due to improvements in its infrastructure, the province of Formosa is a pole of this process. It requires the analysis and continual observation of its quality of soils. In that sense, it is difficult to determine whether a productive system is sustained, and especially if the soil, at medium or long term, doesn't lose quality. There is a great number of definitions about soil quality. Most of them are based on the capacity of fulfilling certain functions: biological sustained productivity (to produce without losing physical, chemical or biological properties), reduce environmental pollutants and pathogens, nutrient cycling, water movement, structural support, resistanceresilience and habitat- biodiversity, among others (Doran and Parkin, 1994; Karlen et al., 1997; Andrews et al., 2004). Although there no exists a universal method to evaluate the changes in soil quality, it is frequent to do it using indicators. 
The quality indicators are edaphic variables sensitive to the handling and the conditions of soil and climate able to synthesize information; they measure, quantify and impart this information (Cantú et al., 2007; García et al., 2012). Thereby, it is necessary the determination of a minimum set of indicators and the assignment of threshold values for them in each region (Wilson and Sione, 2017). The loss of soil quality has been reported in different situations in Formosa. Baridón et al. (2012) recorded the decrease of OOC, light carbon, and TN in a Hapludalf in the west center region (Laguna Yema), after the clearing and ten years of continual agriculture with conventional tillage. Working in Hapludolls and Argiudolls in the northeast area, with higher soil moisture contents, Baridón and Casas (2014), reported marked alterations in their quality after 20 or 25 years of continual use of different productive systems, and defined soil quality indicators.

The studied region, center of the province of Formosa, has a high livestock-agricultural potential with complex soils that include Hapludolls among their components of better productive capacity. There exists an extensive zone of native forests, degraded by wood thinning and grazing with a trend towards the change of using continual agriculture and intensive livestock. The goal of this actual work was to quantify, after five years of clearing, the effects of two management systemsover a Hapludoll in this region of Formosa.

\section{Materials and Methods}

\subsection{General characteristics of the working area.}

This work was done in a representative establishment in the center of Formosa, near $25^{\circ} 24^{\prime} 00^{\prime \prime} \mathrm{S}$., $60^{\circ} 01^{\prime} 30^{\prime}$ 'W. location, Figure 1.

Figure 1.Schematic location of the study area.

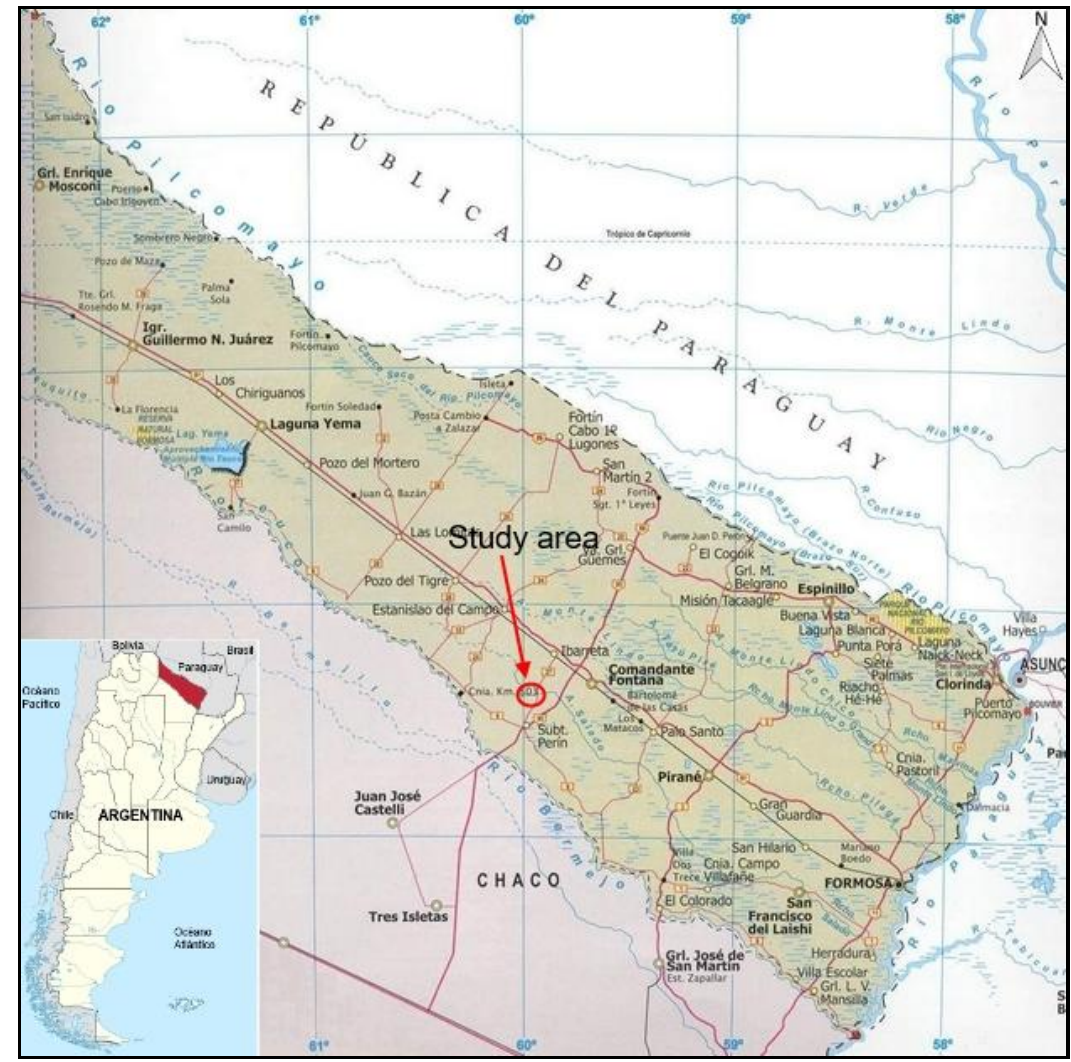

According to INTA (1990), the characteristic soils constitute an association of Haplustoll, Natracualf and Albacualf. However, the climate registers in the zone allow defining the edaphic humidity regime as udic. Thus, the soil with better agricultural suitability for livestock is classified as Hapludoll and it appears in normal reliefs and high hills position. The predominant natural vegetation is composed of tall, open or closed forests. This region is characterized by presenting balance between precipitation and annual evaporation-transpiration, close to $1000 \mathrm{~mm}$ with concentrated rain in summer. 
The average annual temperature is $22^{\circ} \mathrm{C}$ with maximum temperatures exceeding $45^{\circ} \mathrm{C}$. The absolute highest temperatures of greatest risk are reported between June, July and August with the probability of frost. The frequency of frost is 0-8 (Official Formosa Portal, 2005).

\subsection{Productive Systems.}

Three productive systems (PS) which represent the different soil uses were identified: native degraded forest $(\mathrm{NF})$, continual agriculture (CA) andcattle raising (CR). These are the following characteristics of each system:

- Native degraded forest (NF):it constitutes a forest of native species, degraded by grazing, opening bites and thinning of wood. The dominanttrees are: Quebracho colorado (Schinopsislorentzii), Quebracho blanco (Aspidospermasp), Palo santo (Bulnesiasarmientoii), Guayacán (Caesalpiniaparaguariensis) and Algarrobo blanco (Prosopis alba).

-Continual agriculture (CA):it includes an area with continual agriculture in direct sowing, clearance 5 years ago. The clearing was mechanical with bulldozers followed by cordoning off and burning. Later it was de-bred manually, two passes of heavy disc harrow, and two passes of grader blade. Once an agricultural cycle was started, short fallows and chemical weed control continued. The following was the agricultural history of the lot: 2011 clearing; 2012/13 Sunflower (Helliantusannuus); 2013/14 Corn for grain (Zea mays);2014/15 Sorghum for silage(Sorghum spp.); 2015/16 Corn for silage.

-Cattle raising (CR):represented by an area of five- year- clearing with pasture of Gatton panic (Panicum maximum) and Gramarhodes (Chloris gayana).

\subsection{Sample design.}

The sample was done on a Hapludoll in the three SP mentioned before according to a stratified random design. The strata corresponded with the situations of use, native forest (NF), considered as a witness; continual agriculture (CA) and cattle raising (CR). Five sites of sample were distributed at random in each strata. A composed superficial sample of up to $10 \mathrm{~cm}$ deep and another subsuperficial sample of 10 to $20 \mathrm{~cm}$ were extracted in each site. Thirty soil samples were analysed.

\subsection{Soil quality indicators.}

Variables already used as indicators in other regions of the province of Formosa (Baridón et al., 2012; Baridón and Casas,2014) were measured. About the superficial samples $(0-10 \mathrm{~cm})$, it was determined: $\mathrm{pH} 1: 2,5$, potentiometric method, oxidizable organic carbon (OOC), Walkley Black method; particle organic carbon (POC) (Galantini, 2005); total nitrogen (TN), Kjeldahl; structural stability (SS) (Le Bissonnais, 1996)and bulk density (BD), cylinder method (Forsythe, 1975). In the subsuperficial samples $(10-20 \mathrm{~cm})$, it was evaluated $\mathrm{pH}(\mathrm{pHs})$ and bulk density (BDs).

\subsection{Statistical analysis}

In order to characterize the behavior of the variables, descriptive statistic techniques were applied, including the analysis of the variant. The comparison of average was made through Fisher's significant minimum difference test.

\section{Results and Discussion}

The average values of the proposed variables as indicators of quality in the different soil uses, its standard deviations and the existence of different significant statistics, are shown in table 1. It is observed that the average values of $\mathrm{pH}, \mathrm{OOC}, \mathrm{POC}, \mathrm{SS}, \mathrm{BD}$ of the superficial samples and the subsuperficial BDs, showed significant differences among the different uses. To the contrary, TN of the horizon, Ap and sub superficial $\mathrm{pH}(\mathrm{pHs})$, did not indicate statistical differences. 
Table 1.Values of the analyzed variables in each productive system

\begin{tabular}{|c|c|c|c|c|c|c|c|c|c|c|c|}
\hline & \multicolumn{9}{|c|}{ Analyzed variables } \\
\hline & & & pH & $\begin{array}{c}\text { OOC } \\
{\left[{\left.\mathrm{g} . \mathrm{kg}^{-1}\right]}^{-1}\right.}\end{array}$ & $\begin{array}{c}\text { POC } \\
{\left[\text { g.kg }^{-1}\right]}\end{array}$ & $\begin{array}{c}\mathbf{T N} \\
{\left[\mathrm{g}^{\left.-\mathrm{kg}^{-1}\right]}\right.}\end{array}$ & $\begin{array}{c}\mathrm{C} / \mathrm{N} \\
\text { (ratio) }\end{array}$ & $\begin{array}{c}\text { SSwad } \\
{[\mathrm{mm}]}\end{array}$ & $\begin{array}{c}\text { BD } \\
{\left[{\left.\mathrm{g} . \mathrm{cm}^{-3}\right]}^{-3}\right.}\end{array}$ & pHs & $\begin{array}{c}\text { BDs } \\
{\left[{\left.\mathrm{g} . \mathrm{cm}^{-3}\right]}^{-3}\right.}\end{array}$ \\
\hline \multirow{6}{*}{ 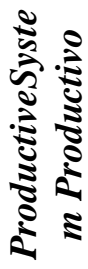 } & \multirow[t]{2}{*}{ CA } & Mean & $7,46_{b}$ & $12,96_{a}$ & $4,83_{\mathrm{a}}$ & $1,07_{\mathrm{a}}$ & 12,1 & $0,58_{\mathrm{a}}$ & $1,42_{b}$ & $7,44_{a}$ & $1,46_{b}$ \\
\hline & & $\mathrm{Sd}$ & 0,37 & 3,87 & 1,92 & 0,28 & --- & 0,12 & 0,07 & 0,31 & 0,08 \\
\hline & \multirow[t]{2}{*}{ CR } & Mean & $7,2_{\mathrm{b}}$ & $19,95_{b}$ & $4,79_{\mathrm{a}}$ & $1,35_{\mathrm{a}}$ & 14,8 & $1,09_{\mathrm{b}}$ & $1,42_{b}$ & $7,94_{a}$ & $1,47_{\mathrm{b}}$ \\
\hline & & $\mathrm{Sd}$ & 0,37 & 4,28 & 1,38 & 0,50 & --- & 0,22 & 0,13 & 0,59 & 0,10 \\
\hline & \multirow[t]{2}{*}{ NF } & Mean & $6,64_{a}$ & $26,04_{c}$ & $13,01_{b}$ & $1,69_{a}$ & 15,4 & $1,39_{b}$ & $1,26_{a}$ & $7,64_{a}$ & $1,29_{\mathrm{a}}$ \\
\hline & & $\mathrm{Sd}$ & 0,25 & 4,54 & 5,82 & 0,53 & ---- & 0,29 & 0,05 & 0,55 & 0,09 \\
\hline
\end{tabular}

CA: Continual agriculture; CR: cattleraising; NF: native forest; Sd: standard deviation; wad: weighted average diameter; abc: different letters show significant differences $(\mathrm{p}<0,05)$

The comparison of means of superficial $\mathrm{pH}$ through Fisher's DMS test, indicates that the $\mathrm{pH}$ in the agricultural and livestock systems differ from the witness, native forest, without significant differences between them (Table 1). In NF, the $\mathrm{pH}$ was slightly acid while in continual agriculture and cattle raising it was slightly alkaline. The cause could be based on the burning of forest stubble, after the clearing, which produces the increase in the superficial $\mathrm{pH}$ of the soil. This reaction is more marked in the first $5 \mathrm{~cm}$ of depth, due to easily available cations coming from the ashes (Mils, 2006).

Table 1 allows observing significant statistical differences between the average values of the oxidizable organic carbon in the Ap horizon. After 5 years, since the change of use, the content of OOC of the forest, $26,04 \mathrm{~g}_{\mathrm{Kg}} \mathrm{Kg}^{-1}$, decreased $23,39 \%$ with livestock use and $50,23 \%$ with continual agriculture in direct sowing. These changes are consistent with other authors reports regarding changes in land use. Albanesi et al. (2003), working on a Entic Haplustoll and on a Typic Argiustoll in the east center of the province of Santiago del Estero, Argentina, concluded that the minor vegetation cover does not reach to protect the soil from excessive heating, stimulating the mineralization of carbon and the formation of compounds with greater instability and more susceptible to microbial degradation. It was detected 14\% of loss of a total organic carbon (TOC) in an Ap horizon of $16 \mathrm{~cm}$ in thickness, with 7 years of continual agriculture. Heredia et al.,(2006)found significant decreases in the content of $\mathrm{C}$ in soils destined to agriculture and these differences were more marked in the first years of conventional agriculture. Baridón and Casas (2014), reported the decrease of $30,75 \%$ of TOC in systems of continual agriculture and the increase of $24,72 \%$ in pastoral systems, in Hapludoll similar to those studied but in a more humid zone of Formosa,25 years after the clearing. It is feasible that this last result is not manifested in the conditions of the actual work yet; due to 5 years of implanted pasture has not been enough to reverse the initial effects of the clearing.

The particulate organic carbon indicator presented statistical differences between Native Forest $\left(13,01 \mathrm{~g} \cdot \mathrm{Kg}^{-1}\right)$, Agriculture $\left(4,77 \mathrm{~g} \cdot \mathrm{Kg}^{-1}\right)$ and Cattle raising $\left(4,83 \mathrm{~g} \cdot \mathrm{Kg}^{-1}\right)$, Table 1; these last ones without any differences between them. Although a loss in OOC of $23.39 \%$ in CR and 50,23\% in CA was previously indicated, the POC loss was more superior in both uses than in the forest witness, close to 63\%.According to Caldwell et al.(2002), this could be explained from the processes of combustion and violent mineralization, in the burning of waste ofthe clearing.

The sensitivity of the structural stability, through different uses and handling in different soils, has been verified (Cerdá, 2000; Ferreras et al., 2007; Álvarez et al., 2008; Baridón and Casas, 2014). It was evaluated through the weighted average diameter of the aggregate after being subjected to the action of water. It is presented in Table 1, and it allows to observe that continual agriculture produced a significant decrease in the SS, while livestock use presented aggregates of average diameters similar to a native forest. Though there was a decreasing tendency inthe $\mathrm{TN}$ of native forest (NF) to continual agriculture (CA), it was not of statistical value and does not follow the same behavior as OOC. This is based on the different nature and composition of the organic material contributed to the soil by each productive system, which is manifested in the relation $\mathrm{C} / \mathrm{N}$, table 1 . Torres et al.(1996) refers to the high $\mathrm{C} / \mathrm{N}$ relation in the Chaco forest, Argentina, produced by the ligneous remains and the high carbon content in the forest litter. The superficial and subsuperficial bulk density values showed significant variations between the different productive systems (Table 1). There was an increase from $1.26{\mathrm{~g} . \mathrm{cm}^{-3}}^{-3}$ in NF to $1.42 \mathrm{~g} . \mathrm{cm}^{-3}$ in CA and CR, in the first centimeters of the soil. 
This increase, as well as the increase in the subsuperficial BD is coincident with that reported by Rojas et al.(2016) in the north west of Chaco. Opposite, Albanesi et al.(2003), reported that pasture sites subject to manual selective clearing and silvopastoral handling, did not show significant differences of the BD with respect to the natural forest. The subsuperficial $\mathrm{pH}(10-20 \mathrm{~cm})$ did not register variations that allow it to be used as an indicator of soil quality under the conditions of this study.

Six of the evaluated variables have presented statistical differences in their average values. Livestock use determined that the soil maintained its quality in terms of OOC and SS. Although it was expected that in the cattle raising system, some indicators will show an improvement in the health of the soil, respect to the degraded native forest, this did not occur. A possible explanation is based on the strong initial impact of the process of agriculturization, when the same starts from the native forest of Formosa.

The movement of soil, machinery transit, burning of residue and exposure of bare soil to rain, high radiation conditions and temperature, constitute an event that would exceed its resilience capacity in the short and medium term. The livestock system, with appropriate management practices, could reverse, in the long term, the degradation of the soil. The loss of chemical and physical fertility of the soil in the continual agriculture system has been deepened. These processes could be reduced and even reversed with good management practices that include, for example, crop rotation and cover crops, among others.

\section{Conclusion}

- Agricultural and livestock systems applied continuously for 5 years in a Hapludoll in the region, produced a decrease in the quality of it.

- Superficial oxidizable organic carbon, particulate organic carbon, structural stability, bulk density and $\mathrm{pH}$ were early indicators in the loss of soil quality.

- The continual agriculture in direct sowing produced the greatest deterioration of the edaphic system.

- Contrary to the expected,5 years of implanted pasture only mitigated the deterioration of the soil, without producing improvements in relation to the degraded forest system.

\section{References}

Albanesi, A.; A. Anriquez \& A. Polo Sánchez. 2003. Efectos de la agricultura convencional en algunas formas del C en una toposecuencia de la Región Chaqueña, Argentina. Agriscientia 20:1-9.

Álvarez, M.F.; M. Osterrieth; V. Laborde \& L. Montti. 2008. Estabilidad, morfología y rugosidad de agregados de Argiudoles típicos sometidos a distintos usos: su rol como indicadores de calidad física en suelos de la provincia de Buenos Aires, Argentina. CI. Suelo (Argentina), 26(2): 115-129.

Andrews, S.S.; D.L. Karlen\& C.A. Cambardella. 2004. The Soil Management Assessment Framework: A Quantitative Soil Quality Evaluation Method. SoilSci. Soc. Am. J., 68: 1945-1962.

Baridón, E.; A. Pellegrini; J. Lanfranco \& V.Cattani, 2012. Variación de la fracción orgánica por agriculturización en Alfisoles subtropicales de Argentina. CienciAgro, 2 (3):371-378.

Baridón J. E. \& R. Casas. 2014. Quality indicators in subtropical soils of Formosa, Argentina: Changes for agriculturization. International Soil and Water Conservation Research 2 (4): 13-24.

Caldwell, T.; D. Johnson; W. Miller \&R. Qualls. 2002. Forest floor carbon and nitrogen losses due to prescription fire. Soil Sci. Soc. Am. J. 66: 262-267.

Cantú, M.P.; A. Becker \& J.C. Bedano. 2007. Evaluación de la calidad de suelos mediante el uso de indicadores e índices. CI. Suelo (Argentina), 25 (2): 173-178.

Cerdá A. 2000. Aggregate stability against water forces under different climates on agriculture land and scrubland in southern Bolivia. Soil \& Tillage Research 57 (2000): 159-166

Doran, W.J. \& B. Parkin. 1994. Defining and Assessing Soil Quality. In: Doran, J.W.; D.C. Coleman; Bezdicek, D.F.; and Stewart, Defining Soil Quality for a Sustainable Environment. SSSA.

Special Publication Number 35. Madison, Wisconsin, pp 3-21

Ferreras, L.; G. Magra; P. Besson; E. Kovalevski \& F. García. 2007. Indicadores de calidad física en suelos de la región pampeana norte de Argentina bajo siembra directa. CI. Suelo (Argentina), 25(2): 159-172.

Forsythe W. 1975. Manual de laboratorio: Física de suelos.Instituto Interamericano de Cooperación para la Agricultura.San José, Costa Rica. 212 pp 
Galantini, J. A. 2005. Separación y análisis de las fracciones orgánicas. En: L. Marbán y S. E. Ratto. (Eds.)Tecnologías en análisis de suelos. Pp 95-106. AACS. Buenos Aires. 215pp

García, Y.; W. Ramírez \&S. Sánchez. 2012. Indicadores de calidad de los suelos: una nueva manera de evaluar este recurso. Pastos y Forrajes, 35 (2): 125-138.

Heredia OS; L Giuffré; FJ Gorleri\& ME Conti. 2006. Calidad de los suelos del norte de Santa Fe. Efecto de la geomorfología y el uso de la tierra. Ci Suelo (Argentina) 24(2):109-114.

INTA. 1990. Atlas de suelo de la República Argentina. Provincia de Formosa.

Karlen, D.L.; M.J. Mausbach; J.W. Doran; R.G. Cline; R.F. Harris y G.E. Schuman. 1997. Soil quality: a concept, definition and framework for evaluation. Soil Science Society of America J., 61: 4-10.

Le Bissonnais, Y. L. 1996. Aggregate stability and assessment of soil crustability and erodibility: I. Theory and methodology. European Journal of soilscience, 47(4), 425-437.

Mils, G H. 2006. Impacto de la quema controlada sobre los principales parámetros químicos del suelo.Revista Marca Liquida Agropecuaria. Available: http://www.produccion-animal.com.ar/produccion_y_manejo_pasturas/uso_del_fuego/01quema_impacto_sobre_suelo.pdf

Population Reference Bureau 2013. Informe anual de evolución de la población mundial. Available:http://www.prb.org/pdf14/2013-population-data-sheet_spanish.pdf

Portal Oficial de Formosa. 2005. Clima y Temperatura. Available:http://www.formosa.gob.ar/miprovincia/aspectosgenerales/climaytemperaturas

Rojas, J.M.; J. Prause; G. Sanzano; O. Ernesto; A. Arce; M. C. Sánchez. 2016.Soil quality indicators selection by mixed models and multivariate techniques in deforested areas for agricultural use in NW of Chaco, Argentina. Soil \& Tillage Research, 155: 250-262

Torres, P. y A. Abril, 1996. Dinámica microbiana del suelo en un desmonte selectivo del Chaco árido Argentino. Ciencia del Suelo, 14: 30-36.

Wilson M.G. y S. Sione. 2017. Selección de indicadores de calidad de suelo. Obtención del conjunto mínimo de indicadores. Criterios para la definición de valores umbrales y obtención de índices. En: Manual de indicadores de calidad del suelo para las ecorregiones de Argentina. INTA. Ediciones 151 pp. Libro digital 